\title{
Individualistic vikings: culture, economics and Iceland
}

\author{
Már Wolfgang Mixa, Adjunct, School of Business, Reykjavik University \\ Vlad Vaiman, Associate Dean and Professor of International Manage- \\ ment, California Lutheran University
}

\begin{abstract}
Icelandic culture has generally been considered to share many similarities to the Nordic cultures. However, the financial crisis in 2008 painted a completely different picture, with the Nordic nations faring much less worse than Iceland, which saw its banking system becoming almost entirely worthless. Looking at traditional cultural yardsticks in the vein of the most commonly used research in the field of business and organizational management, generally linked to Hofstede's dimensional studies, one would at first glance conclude that Icelanders would have behaved in a similar manner as people in the Nordic nations. By focusing on savings ratio, it is shown that Icelanders were much more risk-seeking during the prelude of the crisis. Many nations badly hit during the 2008 financial crisis have a high level of individualism inherent in their culture. Iceland fits this scenario. Thus while general cultural characteristics may lack explanatory power regarding economic behavior of people between cultures, the individual/collective cultural dimension may provide clues of what dangers (and possible strengths) lurk within societies from a financial point of view. Such developments may affect the financial stability of nations, especially those with a high level of individualism where financial liberalization with possible abuses is occurring.
\end{abstract}

Keywords: Behavioral economics; financial crises; Hofstede; individualism; Iceland. 


\section{Introduction}

Icelanders are generally considered to be culturally similar to other Nordic nations regarding, for example, personal traits, institutional systems and visible cultural artefacts (Vaiman et al. 2010), while also showing significant American characteristics (Olafsson 2003). All the Nordic nations are known for established welfare states, similar languages (Finland is the exception), religion and an intertwined history. Although they suffered major blows during the financial crisis that crushed large parts of the world's economy in 2008, Iceland stood out in terms of losses. Almost the entire banking system in Iceland went into receivership during the first two weeks of October of 2008, with credit losses estimated to be in the region of Iceland's annual total Gross Domestic Product (GDP), fourfold (Zoega 2010). Sigurjonsson and Mixa (2011) showed that the growth of the Icelandic banking system was much more reckless in the prelude to the 2008 crisis than the growth among other Nordic banks preceding the major banking crisis during the early 1990s, paving the way for historical losses.

The massive difference raises questions why Iceland suffered a much worse fate than its Nordic counterparts in view of the assumed cultural similarities. The assumption that Nordic financial institutions had simply learned from their early 1990s banking crisis is a weak argument, since the Icelandic government had to inject a similar percentage of the nation's GDP into the banking system during the same period (Gylfason 2011).

Recent research in Iceland has, in an indirect way, shed light on factors indicating that certain socio-cultural conditions during the period preceding the 2008 crash may have influenced why Iceland stood out, particularly by creating a banking system with such speed that it was vulnerable to any sort of domestic or international financial difficulties. Part of that research is mainly built upon Geert Hofstede's methods in investigating certain characteristics of national cultures, which are often referred to as dimensional studies. Such studies have been used extensively in the field of management and business by many scholars in other national contexts (Newman \& Nollen 1996; Soares, Farhangmehr \& Shoham 2007; Hoffman \& Hegarty 1993).

When viewing the general results of Hofstede's dimensional studies, it appears that they break down when inspecting Icelandic behavior from a financial standpoint. The different financial behavior of Icelanders compared to other Nordic nations was already apparent during the mid-1990s, but the divergence gathered considerable strength during the early 2000s. However, this divergence may be less surprising when taking a closer look at comparison studies of the Nordic nations. Smith et al. $(2003,492)$ showed that while the Nordic nations had a common distinctive cultural profile, the authors point out possible differences when reviewing management styles between those nations (494), more so than prior literature might have led them to expect.

In this paper we use Smith's et al. approach of looking closely at certain cultural differences, but instead of focusing on management style, we focus on financial indicators and their potential in inferring possible cultural differences. We show that while Nordic nations appear on the surface to share similar cultural traits, financial data indicates Icelanders being more risk-oriented. By stressing financial data, our discussion can be lo- 


\section{STJÓRNMÁL $\&$ \\ STJÓRNSÝSLA}

cated within cultural economics - a research area that views financial behavior not purely from a singular psychological perspective but is also built upon the assumption that financial behavior is shaped by wider historical and economic contexts and may differ between cultures, even those that on the surface may seem similar. This method enables us to analyze Hofstede's application, its possible weaknesses but also its possibilities.

We begin by providing a short overview of general perceptions of Icelandic culture, showing that while cultural similarities exist between Iceland and the other Nordic nations, there still remain distinct differences. We then provide an overview of cultural economics and then again compare Iceland to certain Nordic nations using financial data to show different indications of cultural behavior. We focus on recent dimensional studies done by Adalsteinsson, Gudmundsdottir and Gudlaugsson (AGG) published in 2011 and 2015 and we provide possible explanations of why the nation was, in a sense, ready to embrace new sets of cultural values. This discussion focuses on the individualism dimension. We also discuss other factors that influenced and were intertwined with changing the Icelandic nation's values and perspective in such a dramatic way. They include the institutional changes that were occurring in Iceland during the mid-1990s within the financial sector, a paradigm shift in political ideologies, and all this taking place at the same time as a technological revolution in communication changed the world view of the Icelandic nation. These combined elements created a perfect financial storm that could show its force at any given moment. We argue that such cultural elements differed in Iceland compared to other Nordic nations, and this explains, to a certain degree, why Iceland was harder hit by the financial crisis in 2008 than the other Nordic nations.

\section{Icelandic culture comparisons}

A common way of measuring cultural differences is dimensional studies, which are usually attributed to Geert Hofstede. Hofstede's methodology compares certain dimensions between nations on a relative scale. This method has been used extensively in the field of management and business by many scholars. Trompenaars \& Hampden-Turner define culture as being a shared system of meanings, dictating what we pay attention to, how we act and what we value $(1998,13)$. That definition is often used as a prelude of Hofstede's et al. $(2011,6)$ definition; "Culture is the collective programming of the mind that distinguishes the members of one group or category of people from others." Both parties define culture as being in layers from which external observations of culture are observed towards more unobservable aspects that are more inherent values.

Hofstede's methods have been criticized by numerous researchers (Ailon 2008; McSweeney 2002) but nevertheless remain the most popular method in studying crossnational cultures within financial analysis (Breuer \& Quinten 2009; Magnusson et al. 2008; Reuter 2010), with no obvious alternatives (Jones 2007). Hofstede's dimensions in comparing different cultural differences are grouped into five categories: 1) Power Distance (PDI), which measures the extent to which members with less power within institutions and organizations expect and accept an unequal distribution of power; 2) 


\section{STJÓRNSÝSLA}

Individualism (versus Collectivism) (IDV), which refers to societies where ties between individuals are loose as opposed to other ones where people place a more emphasis on strong and cohesive in-groups; 3) Masculinity versus Femininity (MAS), a dimension relating to gender roles of various types; 4) Uncertainty - Avoidance (UAI), a scaled level of members' inclination to avoid or feel threatened by unknown situations and thus inclinations of having a structured life; 5) Long-term versus Short-term Orientation (LTO), which is an indicator for the emphasis on future, as opposed to immediate, rewards, especially concerning actions of perseverance and thrift.

Only a few studies relying on Hofstede's research have been conducted in Iceland, with the Hofstede database website stating that Iceland's scores are merely, "based on an educated guess derived from data representing similar countries in combination with our practitioner experience" (Hofstede Centre 2015). In 1997, Eyjolfsdottir and Smith examined the Icelandic pattern of business and management relating to Iceland's culture, relying mainly upon a questionnaire study, from which they developed an analysis using Hofstede's concepts. No numeric scores were provided, but nevertheless general conclusions were made. Their findings of Icelandic management culture suggest similarities to other Nordic nations, with Icelandic managers in general resembling their Nordic counterparts with low power distance, low uncertainty avoidance and holding feminine values. The individualism findings indicated, however, that Icelandic managers were more individualistic than their Nordic counterparts and actually similar to other nations where the highest scores in the world were recorded, such as the United States, the Netherlands, Australia, Sweden and the United Kingdom (67). Although the Longterm dimension was not set up in conjunction with Hofstede's research - it had recently been added when that study was done, therefore, Eyjolfsdottir and Smith were probably not aware of it during the writing of the paper - a great deal is spent on inferring such practices, drawing upon Trompeaars and Hampden-Turner's dimension of time and emphasis on short- versus long-term results. Their conclusion is that Icelandic managers concentrate on short-term results, having "a fisherman's mentality" of dealing with an unstable environment (69-70).

H.P. Jonsson used the Hofstede questionnaire (2004) to compare one company and one institution in Iceland to other comparable ones in the Nordic nations. The general results were that Icelanders are culturally similar to Nordic nations. However, the findings showed that Icelanders had more power distance, slightly more individualism, their masculinity was in the higher range, and Icelanders had the highest uncertainty avoidance and long-term orientation of the Nordic nations (LTO was not measured for Denmark and Finland). It should be noted that while the Icelandic stock market had recently given fantastic returns when the study was done, many Icelanders at that point were still licking their wounds from dot.com investments, in particular relating to enormous losses related to the bio-technological company deCODE genetics. The result of the study outlined above, particularly regarding individualism, is similar to Geert Hofstede's own estimates (long-term orientation not included) when he was interviewed by Vlad Vaiman 


\section{STJÓRNSÝSLA}

in 2009 (Vaiman, Davidsson \& Sigurjonsson 2010). However, Hofstede estimated lower scores in the other dimensions.

The first Icelandic systematic comparison study in the dimensional manner was conducted in 2009 by Adalsteinsson, Gudmundsdottir \& Gudlaugsson (AGG) (2011). According to their results, Icelandic culture entails a low power distance, high feminine values and average long-term orientation compared to other Nordic nations. It is interesting that the uncertainty avoidance dimension is relatively high within the Icelandic culture. AGG point out that the uncertainty avoidance dimension may be influenced by the recent financial crash, and related financial losses the Icelandic nation had endured (360). The main distinct result relates to individualism. Iceland not only scored higher than the Nordic nations regarding individualism but, as AGG point out in their first study, is the first nation since Hofstede's measurements began in 1980 to score higher than the United States.

A follow-up study by the same authors was conducted in 2013, which analyzed its results from various perspectives (Gudmundsdottir, Gudlaugsson \& Adalsteinsson 2015). The general results were similar to their previous study. Figure 1 shows the scores for the Nordic nations compared to Iceland, according to the Hofstede database, using the average scores from the two AGG studies.

Figure 1. Dimensional Studies: Iceland and Nordic Nations.

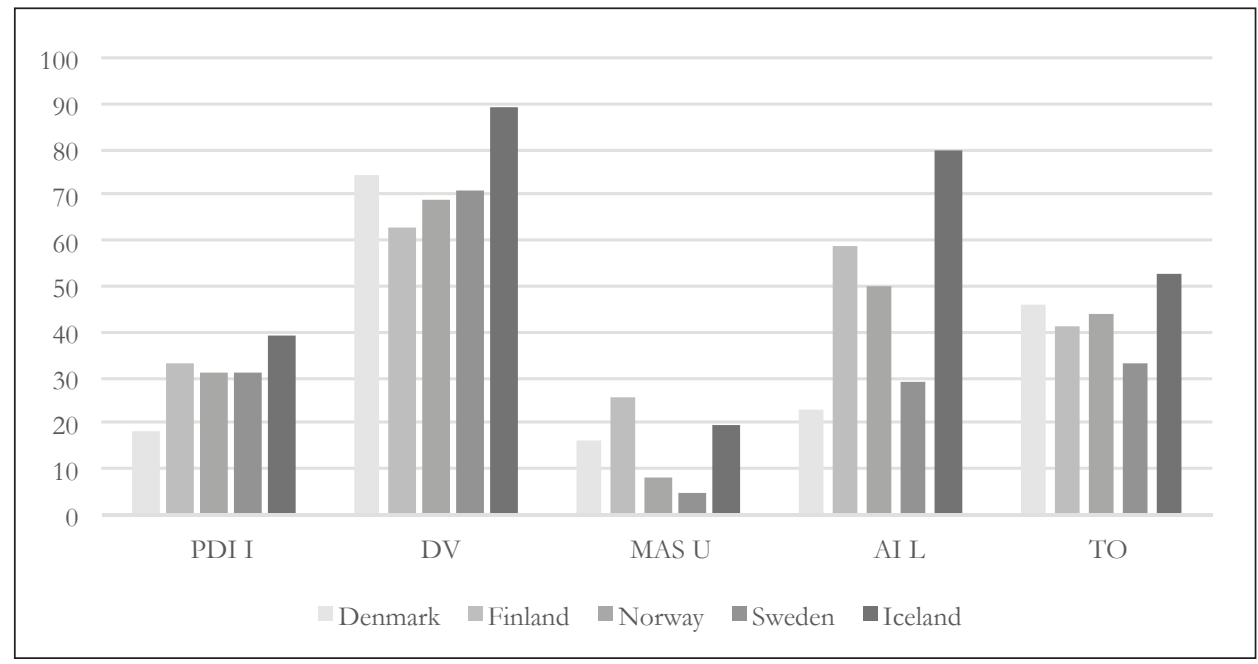

Sources: Hofstede database (2015), Adalsteinsson, Gudmundsdottir \& Gudlaugsson (2011) and Gudmundsdottir, Gudlaugsson \& Adalsteinsson (2015).

In conjunction with their follow-up study in 2014, AGG compared Iceland to 25 other OECD nations and clustered them into groups, depending on similarities of cultural attributes. This resulted in Denmark, Norway and Sweden being clustered together but 


\section{STJÓRNSÝSLA}

without Iceland, which differed from those nations particularly regarding its high individualism. Iceland was instead clustered with Canada, New Zealand, the United Kingdom, Australia and the United States. This strongly indicates that Iceland should not automatically be culturally lumped with other Nordic nations, despite having some similar cultural characteristics. One can thus conclude from these results that while the common perception of Icelandic culture being similar to Nordic cultures is not necessarily incorrect, Icelandic culture exhibits clear patterns of dissimilarity.

What is specifically interesting is the high association with individualism. Four of the five nations grouped with Iceland have the highest individualism score in Hofstede's database, with Iceland rounding up the top 5 group. The final nation grouped with Iceland, New Zealand, has the eighth highest individualism score. This seems to be in accord with a perception of American influences with more individualistic values as Olafsson (2003) proposes in his paper. There are four nations that have by far the highest scores as seen in Figure 2, with Icelandic data being the average scores from the two AGG studies.

\section{Figure 2. Most individualistic nations in the world}

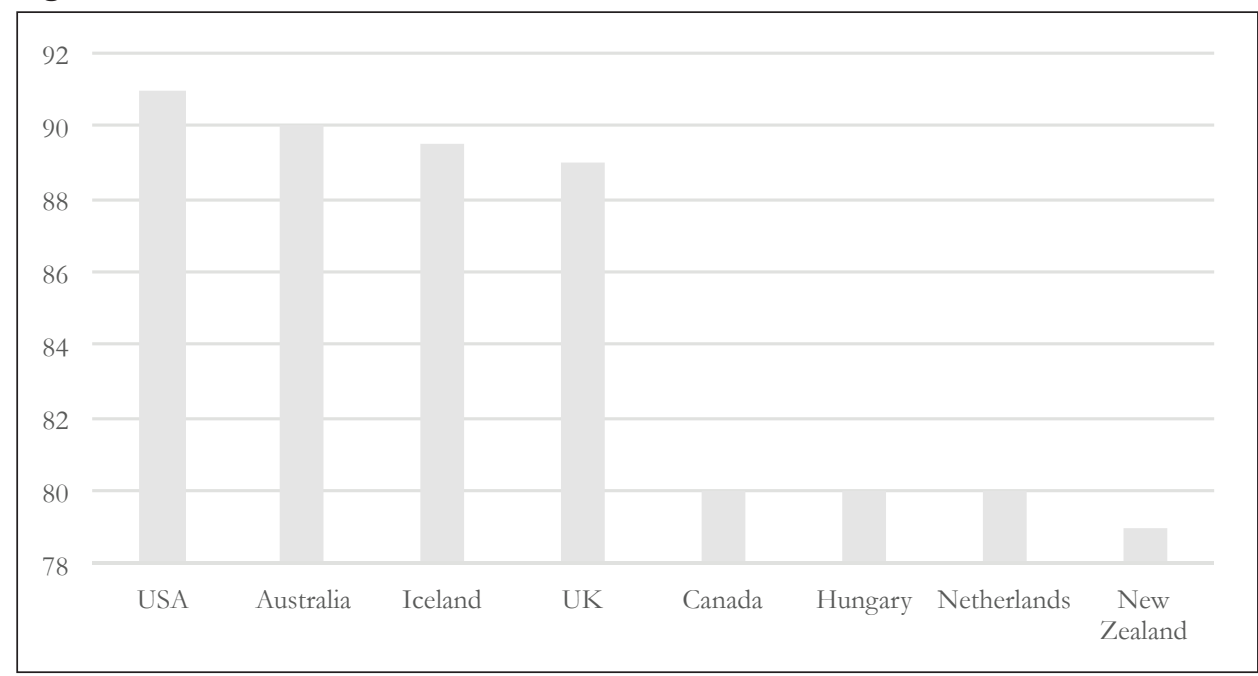

Sources: Hofstede database (2015) and AGG (2011, 2015)

Does this individualistic trend have any implications? While the cause and effect regarding financial matters may be scientifically impossible to prove, the high level of individualism may explain, to a certain degree, the financial behavior of Icelanders. We show that the financial data largely corresponds to individualism, providing an explanation of cultural differences between Icelanders and their Nordic cousins, with Icelanders being more American as Olafsson (2003) infers. This methodology is in line with Hofstede's et al. views, stating that dimensional studies should be first and foremost be used as some sort of stepping stone in applications to other studies (2010, 48-49). 


\section{STJÓRNMÁL \& \\ STJÓRNSÝSLA}

\section{Cultural economics}

Using financial indicators in relation to different cultures is a relatively new way of studying financial behavior and is generally labeled as cultural economics (while the term is often defined as cultural finance, we prefer using the broader term cultural economics, delimiting the term to acts of investments). Cultural economics is conceptualized as being a bridge between a neoclassical point of view of finance and behavioral finance. It is assumed within the neoclassical ideology that market players are purely rational agents towards money and obey laws and regulations within parameters that provide no place for corruption (Cassidy 2009). In contrast, behavioral economics (often termed behavioral finance), a study that has gained momentum since the early 1990s (Shiller 2001), analyzes more cognitive and emotional factors related to individual decision making, showing that people in certain circumstances act in ways that can be questioned as being rational regarding financial matters. Cultural economics takes this one step further by differentiating between such irrationalities as dependent upon cultural values, and even questions if there is a singular 'correct' rationality but simply different core value systems that differ in what constitutes prudent uses of money. These various approaches demonstrate the importance of viewing finance from a multidisciplinary perspective.

A case in point is that behavioral economics generally take individuals raised in particular cultural environments as the norm, thus ignoring cultural aspects as important in shaping people's behavior. The study of behavioral economics generally assumes that what applies to individuals in one culture applies in the same manner in other cultures (at least to great extent). Hofstede $(2010,128)$ takes Adam Smith's theory regarding the "invisible hand" as an example of a generally world-wide accepted theory within the heart of economics. Smith's theory regarding the science of economics is, however, based on an individualistic idea that has been mainly explored within nations that score highly on individualism, meaning that its applicability may differ between territories. The classic case of the tragedy of the commons may, for example, be more relevant in certain cultures than others. The notion of individualism, as understood in behavioral economics, is not necessarily a universal phenomenon, but culturally a specific one, with duties and relations between individuals being different in various cultures.

A common drawback of Hofstede's methods is that they are built upon surveys (Jones 2007) and thus mirror people's perception of themselves contrasted to others, but not necessarily their actual behavior. Opposed to surveys that provide clues about people's perception of themselves and their actions, the use of money provides insights into how people actually act, since financial indicators reflect what individuals have already done in practice, although not revealing the underlying reasons. Here we use financial data to determine differing behaviors between cultures. Such data has historically been used to determine various financial developments, mostly in regard to financial shocks and the explanatory use of financial statistics in determining the causes and consequences of financial crises. Here we use it as a lens to get better insights into different financial behavior as it varies between nations.

In the next chapter we look at financial indicators that reveal behavior from a cultural 
economics standpoint, and then briefly show how financial behavior in Iceland has to be contextualized within the rapid cultural changes that have taken place globally for the last few decades.

\section{Economic and financial comparisons}

Hofstede's research has shown parallels between certain cultural traits and financial behavior (Hofstede et al. 2010). A high level of individualism is, for example, most common in nations that are wealthy but GDP growth in nations with such cultural traits normally lags, in contrast with a common assumption that individualism creates high economic growth. Another example is how thrifty nations are, a cultural trait related to long-term orientation. Thrift, often associated with the percentage of savings compared to income (commonly referred to as the savings ratio), has been associated with high long-term economic growth, although the data in recent years has not been conclusive (Hofstede et al. 2010, 262-267). We elaborate these insights by Hofstede and augment them by stressing the importance of rapid cultural changes that have been largely ignored by other dimensional scholars (Vaiman \& Holden 2015).

\subsection{Stocks and real estate}

Sigurjonsson \& Mixa (2011) compared Icelandic financial figures to ones in the Nordic nations (Sweden, Norway, Finland and Denmark). The comparison periods were preludes of major financial crises, which in the Nordic nations took place from 1982 to 1991 and in Iceland 17 years later, between the years 1999 to 2008. The year 1982 was the starting point (or period 0 (zero)), for the Nordic nations and 1998 in Iceland. Those periods were then compared side by side. They concluded that Iceland had imitated all of the main features of the other nations listed above, but simply to a greater extent. This is, for example, vividly demonstrated by comparing the cumulative lending growth of Icelandic banks to Nordic banks during the comparison periods as seen in Figure 3. It should be noted that Icelandic banks differed from the Nordic banks in a fundamental way because much of the lending among Icelandic banks was, in reality, vehicles to finance speculative purchases, even of their own stock (Sigurjonsson \& Mixa 2011). Increased lending was mostly related to real estate and the stock market in the Nordic nations (Jonung, Kiander \& Vartia 2008, 21). 
Figure 3. Cumulative lending growth comparisons with 1 as a base at period $0-$ domestic credit provided by banking sector \% of GDP - Iceland vs. Nordic nations

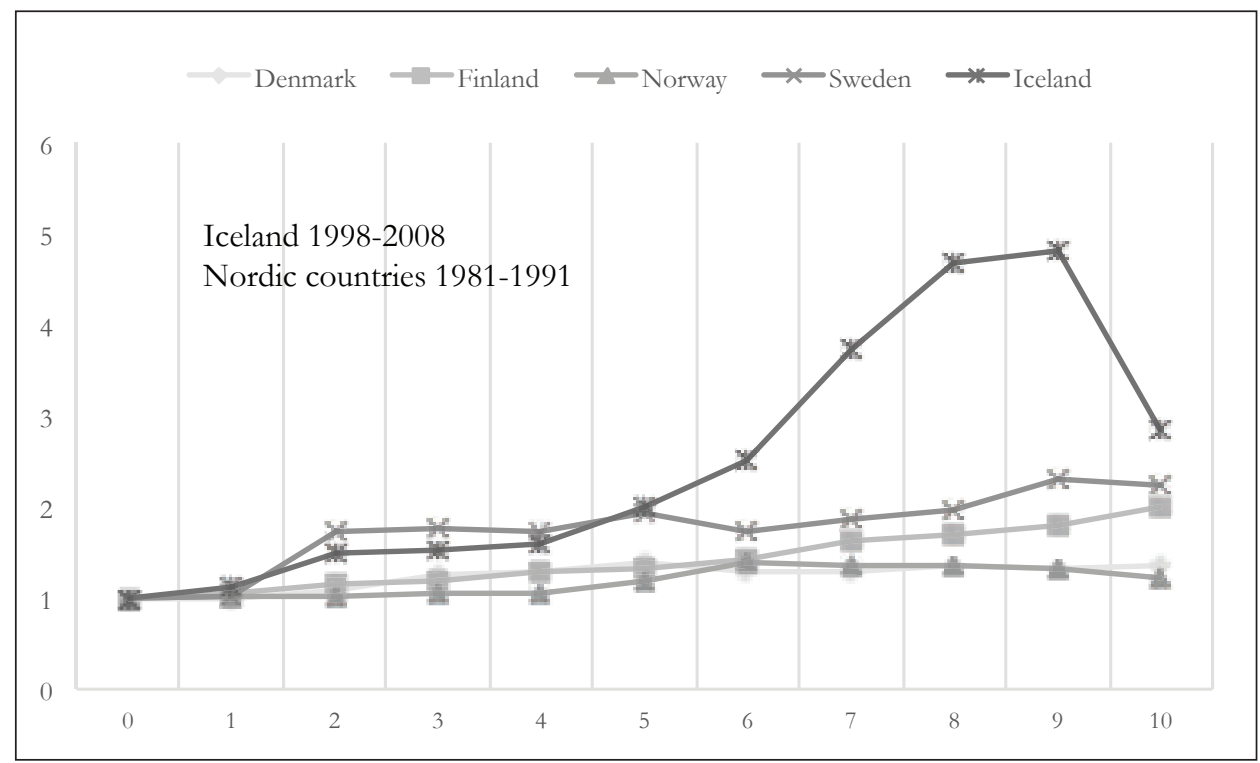

Source: World Bank via Datamarket (2013)

A common indicator of financial analysis in determining behavior within societies is measured with stock market indices and real estate prices, which mirror to a great extent pessimism and optimism within nations. The growth of the Icelandic stock market and rising real estate values from 2002 until the crash was historically unheard of. During these 'Manic Millennium' years (Mixa 2009) stocks multiplied in value more than sevenfold (OMX database 2012) while real estate prices increased threefold (Registers Iceland 2012). Stocks rose the same or more each year in Iceland over the years 2003 (54\%), 2004 (57\%) and 2005 (60\%) (OMX database 2012). This was a similar or greater rise than in 1933 (54\%), which was the best year of US stocks during the 20th century (Fridson 1998, vi-vii). However, that rise occurred after the Dow Jones stock index had fallen almost $90 \%$ in the previous 3 years. The remarkable rise is still almost dwarfed by the sudden fall in equity prices, with the Icelandic market practically wiped out in the fall of 2008 with the nation (literally) in a state of shock. Even compared to the rise and fall of other stock markets in the international arena, Iceland clearly stood out as shown in Figure 4, which compares the stock market index in Iceland to Nordic stock market indices. 
Figure 4. Stock indices in Nordic nations with the base set at 1 at the beginning of 1999 - Iceland vs. Nordic nations.

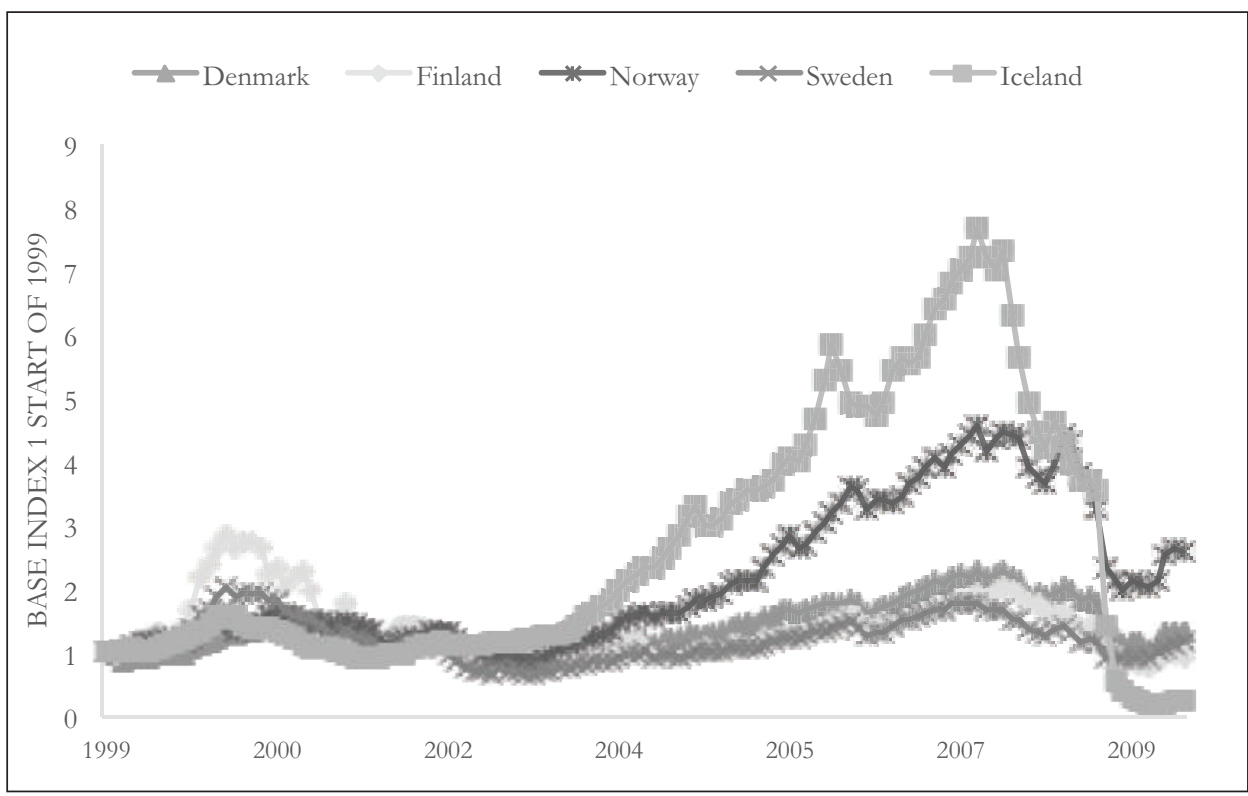

Source: Eurostat via Datamarket (2012)

Whatever the reasons for this divergence between Iceland and the Nordic nations (that were still by no means pessimistic), the difference in the euphoria in the stock market is staggering and does not harmonize with the results of the general and dimensional studies comparing Iceland to Nordic nations.

\subsection{Savings ratio}

The savings ratio is an indicator of how thrifty nations are: it measures the percentage of income that is set aside for the future as opposed to spending all income for more immediate gratification. The ratio is measured by comparing the gross national savings to the percentage of GDP. In other words, if a nation produces goods and services valued at $\$ 100$ per year and consumes $\$ 90$ of it, the remaining $\$ 10$ are saved for the future and comprise $10 \%$ of the GDP. Figure 5 compares the savings ratio between Nordic nations from 1995 until 2014. 
Figure 5. Savings ratio in Nordic nations 1995-2014

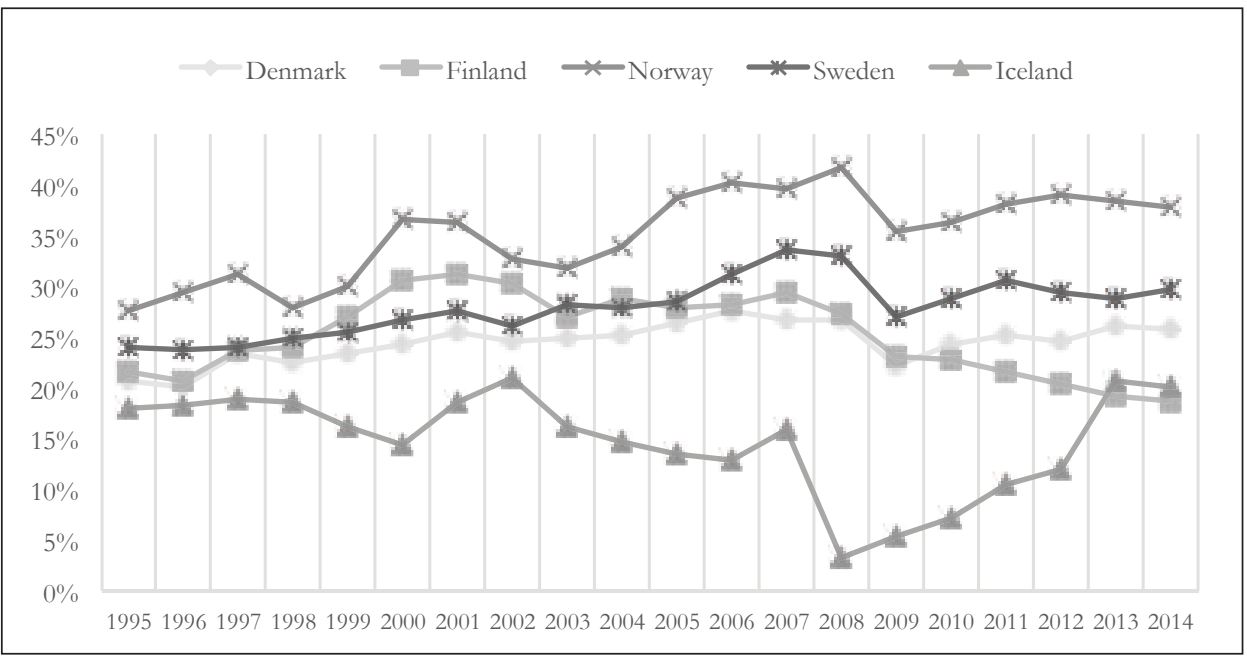

Source: International Monetary Fund (IMF) Database (2015)

Figure 5 shows that Norway has saved between $20-40 \%$ of its GDP during most of the comparison period, and being as high as 30-40\% during the 2000s. This high percentage is distorted though by the fact that its direct proceeds from oil profits are set into a specific investment fund, and with the rise in oil prices the figure has been very high during the most recent decade. The other Scandinavian nations show similar savings ratios. Since all nations are relatively wealthy with socialized systems, the difference cannot be attributed to varying needs to save for a contingency fund.

While the Nordic nations began again to increase their savings ratio up to or above $20 \%$ following the unwinding of the banking crisis during the early 1990s, Iceland showed by far the least inclination to save money. The average savings ratio for Iceland during the 20 year period is $15 \%$, or $10 \%$ lower than the average ratio of the second lowest nations, Denmark and Finland. It is particularly interesting that the difference between the savings ratio between Iceland and the other Nordic nations begins steadily increasing after 1995 with the exception of the period following the dot.com bust during the beginning of the Millennium, and the 2008 crash.

When comparing the savings ratio between nations with high individualism scores to other nations, a clear pattern emerges. The higher the individualism score of nations, the lower the savings ratio tends to be. By analyzing the savings ratio of the four nations with the highest individualism score to the ones with the fifth to eighth highest score, the savings ratio is consistently lower among the highest individualism nations. When the savings ratio of the top 8 individualism nations is further compared to other nations, in this instance the 18 additional nations used in the AGG study (2015) comparing Iceland to 25 other OECD nations, the results show again a negative correlation between the level of individualism and the propensity to save, as seen in Figure 6. 


\section{STJÓRNSÝSLA}

Figure 6. Different level of savings between high IDV nations and other nations 1995-2014

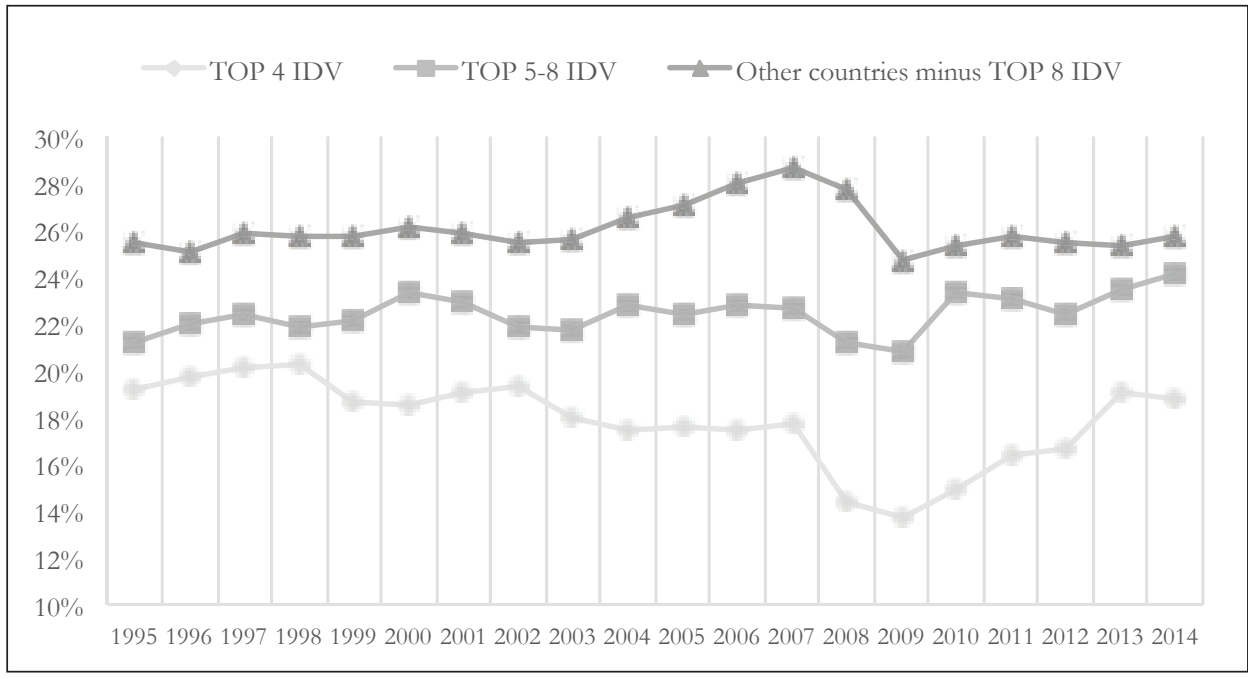

Source: IMF database (2015), Hofstede database (2015), AGG (2011) \& (2015)

The difference is significant. The average savings ratio is $18 \%$ for the top 4 IDV nations, $22 \%$ for the top $5-8$ nations and $26 \%$ for the remaining nations. The savings ratio for Denmark, Finland and Sweden are similar to the remaining nations, or 25\%, 25\% and $28 \%$ respectively. It is interesting that this gap became the highest during the years both before and after the 2008 financial crisis. When looking at the savings ratio of the top 4 IDV nations, Australia stands out as having an average savings ratio of $22 \%$. This is the same as the average of the top 5-8 nations. Iceland, the United Kingdom and the United States have average ratios around 15\%-18\%, with Iceland's numbers lowest. This is possibly due to the very low ratio during years the stock market was rising in an oncein-a-lifetime manner, making people's perception of the need to save for a rainy day almost non-existent. The difference between savings ratios among the top four nations and other nations, especially those outside of the top 8 individualism score, is constantly increasing from 2001. That coincides with the period following the effects of more liquidity, with investment banks and commercial banks becoming ever more merged following the abolishment of the Glass-Steagall Act in 1999, which had prevented such banking practices since 1933 in the wake of the Great Depression.

What is the cause of this divergence? We propose that a sudden change of values, a paradigm shift in worldviews, has occurred in Iceland to a much larger degree than in other Nordic nations, a change that may or may not be permanent. While no studies of general cultural Icelandic characteristics existed in a dimensional manner until recently, making systematic relative comparisons impossible, there are still numerous studies suggesting that Icelanders have historically perceived themselves as individualistic in the 
past (Olafsson 2003; Eyjolfsdottir \& Smith 1997; Matthiasdottir 2004). That notion was, however, still constantly in a tug of war of another notion of holding on to past old-fashioned values (Matthiasdottir 2004, 361-362). This is reflected within the banking system in Iceland, which reflected a course towards a capitalistic (individualistic) modern society, but was yet dominated by centralized (collective) political monitoring (Loftsdottir \& Mixa 2014). That shift largely relates to Iceland's more Americanized culture and high individualistic scores that took shape during the mid-1990s as we describe in the next chapter.

\section{Contextualizing the cultural landscape}

In their discussion on cross-cultural management, Vaiman \& Holden $(2015,58)$ argue that the use of nation as a proxy for culture is insufficient in providing explanations of measurements of values; other non-cultural issues also paradoxically play a part in shaping culture. As Magala $(2015,367)$ points out, cultures constantly evolve and the world has evolved dramatically since Hofstede's initial research was published in 1980, when "neither Google, nor Facebook, nor Amazon.com were available to every owner of a smart phone." We believe that Icelandic culture has rapidly changed during the last two decades, to a great extent due to non-cultural issues that are related to changes in the political and financial landscape, enabled and caused partially by major technological changes in the communication sector.

Hofstede et al. (2010) point out that increasing individualism since the 1990s has been one of the forces leading to deregulation, further stating that certain public monopolies have, in some cases, been replaced for ideological reasons rather than pragmatic ones. This trend of deregulation can be seen as a part of the general process of neoliberalism, closely related to the neoclassical ideology. In defining neoliberalism, Steger and Roy (2010) state that the ideology emphasizes individual empowerment and that central state power should be cut into smaller units with political governance at the same time being minimized. This description fits well with the general description Olafsson (2003) proposed as being the main characteristics of Icelanders, having a strong sense of individualism and independence and resenting central authority.

To provide an answer to how this transformed Icelandic society on a particular dimensional level, while other dimensions did not necessary change, it is worthwhile taking a quick look at Iceland's banking history in relation to its society and how it quickly transformed, changing not only the financial landscape alone but also the societal structure. One of Hofstede's assumptions in his cultural comparisons is that despite cultures gradually changing, they usually do so only during a long period of time (Hofstede et al. 2010). The period since the early 1990s may, however, be an exception to such an assumption. We propose that ideological forces of market efficiency sweeping most of the globe during the period from the 1980s onwards, gaining full steam following the fall of the Berlin Wall, had unequal effects on nations depending on their perceptions of individualism.

Iceland went through a drastic transformation with its borders opening up towards 


\section{STJÓRNSÝSLA}

financial liberalization in 1995, with many of the state's assets being sold, including the three main banks. After having been localized institutions and operating under the rule of political parties in a restricted environment since 1930, the sudden change in the Icelandic financial landscape opened doors for massive profits, but also little experience of the associated risks. Icelandic banks had historically been very centralized. Instead of banks being set up for purely business practices, as was done in 1904 when the first commercial bank was established by Danish investors (Jonsson 2009), banks were almost solely established by collective groups and areas, which was reflected in their names like the Agricultural Bank (Búnaðarbanki Íslands), the Icelandic Bank of Commerce (Verzllunarbanki Íslands) and the Savings Bank of Engineers (Sparisjódur vélstjóra). Many state companies were sold during the 1990s, among them the three major national banks. Institutions became thus less "collective" and more "individualistic" with the focus changing from providing customers services, to increasing profits, with the names of banks no longer being localized to groups (most of the smaller banks established by collective groups were, in 1990, merged into Islandsbanki) and savings banks mostly using acronyms (Savings Bank of Hafnarfjordur became for example known as SPH) as opposed to their names reflecting the local constituency they traditionally served (Loftsdóttir \& Mixa 2014). Berg (1998) points out that in an economic environment where liberalization within banking is taking place, as occurred in the Nordic nations during the 1980s, banks lose their monopolistic powers and the interest rate spread decreases, leading to a contraction in profits. Banks in the Nordic region, as is common under such circumstances (for example Iceland during the Manic Millennium years), began swelling the balance sheet to keep profits increasing but had little experience of the associated risks. Additionally, Icelanders became, during the latter part of the 1990s, suddenly wired to the world of media and finance with the use of the internet, the lower cost of international phone calls and the international live broadcasting of television stations such as CNBC. There was even the opportunity to invest in international financial markets via internet.

As the rise in Icelandic stock market prices prior to the bust in 2008 indicates, there was a perceived sense of phenomenal success due to the massive growth in the banking and financial sector. The public believed that Icelandic bankers were among the best in the world, despite the fact that modernized banking in Iceland was in reality only a few years old and as Thorvaldsson (2009), a former banker at Kaupthing bank, describes, had learned the basics of investment banking only a few years earlier.

One of the typical anatomies Shiller (2001) suggests being among the precipitating factors of a financial bubble, one that Iceland and the United States had in common during the recent financial bubble build-up (Mixa 2009, 436), is the expansion of defined contribution pension plans. Danielsson (2012) concludes that the increase of such plans in Iceland may have contributed to Icelanders' lesser needs in setting aside money for the future, but in a contradictory way people seem to save even less on the whole (or put another way, spend more than they set aside in savings) than before. Dumenil and Levy (2011, 143-155) contend that where neoliberal influences are rampant, more 


\section{STJÓRNMÁL \& \\ STJÓRNSÝSLA}

leverage is prevalent with the savings ratio falling ever more. This may explain why dimensional indicators diverge from financial ones in explaining the behavior of savings and risk appetite among nations. By looking at savings ratios of nations with the highest individualistic scores from Hofstede's dimensional studies, it becomes apparent that such nations have in common very low savings ratios that tend to have decreased further concomitantly as neoliberal influences have grown. While Hondroyiannis (2006, 556-557) summarizes studies showing that the private savings ratio falls within nations following financial liberalization, the savings ratio in Iceland was already below the average of other Nordic nations when the liberalization of its banking system began. Therefore, it simply increased following the financial liberalization, just as other individualistic nations saw their savings ratio decline more than other nations following the financial liberalization of allowing investment banking becoming part of the commercial banking business model.

The Demirguc-Kunt and Detragiache (1998) study of the effects of banking liberalization concludes that the fragility of the banking sector increases when certain factors are not in place, among which is a low level of corruption. They contend that the fragility of the banking sector tends to surface not immediately after a liberalization process begins but a few years later (ibid, 4), warning that financial liberalization should be approached cautiously. There was, however, little caution associated with the Icelandic financial liberalization. The swift changes of Iceland's financial institutions enabled many to become rich rather quickly. Arnason (2015, 48-49) points out that while there may have been a tendency among Icelanders to blame the crash on a handful of local bankers, the success stories of the Icelandic banks, often largely fabricated, were part of an image-making machine. Arnason further asks who should have resisted such processes, as opposed to guarding the public interests. Gylfason $(2012,9)$ points out that many Icelandic politicians owed the banks enormous amounts of money, with 10 out of 63 members of parliament owing the banks more than the equivalence of one million euros each, with campaign donations per person in the Icelandic 2006 elections being 14 times as much as the 2008 US campaign donations. The comparison is even more interesting in light of the fact that the financial sector donates the highest campaign contributions than any other sector in the US (Johnson \& Kwak 2011). Many politicians participated in glorifying the invented rhetoric of Iceland's banks success stories, seeing it, for example, in some way related to the (independent) Viking spirit of the Icelandic bankers (Loftsdottir 2010), where "the economic adventure was seen [...] as a joint project of Iceland and Icelanders, reflecting the national Icelandic character as such, rather than the success of a few men who had joined the ranks of global elite." (Loftsdóttir 2015, 7).

This was easily carried out since most of the media was owned by the same owners as the banks or their main associates, sending constant messages amplifying such perceptions (Askelsdottir 2009). Arnason $(2015,51)$ points out that the authorities that facilitated the growth of the Icelandic banks stood paralyzed once the horrific effects became clear, concluding that many social actors enabled background conditions to 


\section{STJÓRNSÝSLA}

contribute to the event (ibid, 59). A feedback loop within Iceland's society was thus created, to an extent based on merits of strong individualism, where success stories were re-affirmed within banks, while the bankers had hardly any investment banking experience, as described by Thorvaldsson (2009). This corresponds to what Davies and McGoey (2012) term 'rational ignorance,' where agents in the financial markets may make ignorant decisions that may be beneficial in the short run but eventually causing disaster, hence having enough knowledge to promote growth but not enough knowledge to take responsibility.

These sudden changes in the financial arena, coupled with other social transformations (such as the internet and thus connecting to a wider media world), may explain why Iceland's value system has swayed more in line with value systems of the United States and the United Kingdom - nations that have historically had a financial system tied to stock markets with a total market capitalization among the highest in the world (World Bank Database 2015). While it cannot be determined whether it was by default or design, Icelanders were nurtured in enabling the banks to grow to levels that obviously entailed great risks the Icelandic nation bore to a large extent. A lesson learned is that nations with a high degree of individualism may be more apt to financial disasters when liberalizing their financial system; and not only because of their financial behavior but also because they may be more likely to accept success stories that often occur during the first years following liberalization and continue on a reckless financial path. Thus, instead of heeding Demirguc-Kunt and Detragiache's warnings (1998) regarding the dangers associated with financial liberalization, the Icelandic nation collectively championed risky banking business.

\section{Conclusion}

Sectorial features (bankers and their risky behavior) were in Iceland (and generally world-wide) more or less in line with predominant cultural values in conjunction with neoliberal policies, which we show in this paper has links and even re-enforcing effects on increased individualism. Although the sense of individualism world-wide is difficult to measure, since it is relative between nations rather than an absolute number, financial indicators such as the savings ratio appears to provide clues of cultural behavior on both a relative scale between nations and absolute scale regarding general cultural trends for certain areas. With elements such as increased flow of communication (cheaper phone rates and the internet) and the fall of the Berlin Wall implying a victory of Capitalism over Communism, the western world was ripe for a sudden transformation often associated with financial bubbles. The Icelandic nation, having lived relatively isolated for many years due to its geographical location, was certainly riper than most other nations to such international trends and very likely changed much more rapidly than assumed in Hofstede's work.

This change, although unusually sudden, is not an anomaly. History shows that the definition of culture has often been intertwined with economic developments, such as Adam Smith noted when writing The Wealth of Nations, not merely describing economic 


\section{STJÓRNMÁL \& \\ STJÓRNSÝSLA}

concepts but more in a sense the cultural developments he was witnessing within a society quickly transforming into a market economy on the brink of the industrial revolution (Beugelsdijk \& Maseland 2011). Icelandic society, including its banking culture, transformed in a few years from being almost purely domestically focused to becoming highly international oriented.

It could thus be argued that the high degree of individualism within Icelandic society increased the likelihood of it blindly embracing new opportunities within the financial sector. Culture by itself certainly does not, however, explain why such a large part of the population went along. There were major changes within Iceland's financial institutions that quickly changed people's attitudes that cannot be ascribed to some core values within the Icelandic culture. The effects of the relationship between the general culture and sectorial features within it, especially in relation to finance, need further studies to show potential links of the interplay of culture and financial issues. Such studies must take into account other factors such as the long history of political and economic isolation (Sigurjonsson, Schwartzkopf \& Arnardottir 2011) that are beyond the scope of this paper.

\section{References}

Adalsteinsson, G.D., Gudmundsdottir, S., and Gudlaugsson, T.O. (2011). "Íslensk pjóðmenning í ljósi menningarvídda Hofstede" [Icelandic Cultural Nationality within Hofstede’s Culture Dimensions], Icelandic Review of Politics and Administration 7(2), 353-368.

Ailon, G. (2008). "Mirror, mirror on the wall: Culture's consequences in a value test of its own design", The Academy of Management Review 33(4), 885-904.

Arnason, V. (2015). "Something rotten in the state of Iceland: "The production of truth" about the Icelandic banks", in E.P. Durrenberger and G. Palsson (eds.), Gambling Debt: Iceland's rise and fall in the global economy, (pp. 47-62). Boulder: University Press of Colorado.

Berg, S. (1998). "Bank failures in Scandinavia", in J.E. Hughes and S.B. MacDonald (eds.), International banking: Text and cases, (pp. 198-207). Hong Kong: Pearson Education Asia Limited and Tsinghua University Press.

Beugelsdijk, S. and Maseland R. (2011). Culture in economics: bistory, methodological reflections, and contemporary applications. Cambridge: University Press.

Breuer, W. and Quinten, B. (2009). "Cultural finance", Working paper series. Retrieved from http:// papers.ssrn.com/sol3/papers.cfm?abstract_id=1282068.

Cassidy, J. (2009). How markets fail: The logic of economic calamities. New York: Farrar, Straus and Giroux.

Danielsson, A. (2012). "Mandatory pension savings, private savings, homeownership, and financial stability", Working paper Central Bank of Iceland no. 58. Retrieved from http://www.sedlabanki.is/ lisalib/getfile.aspx?itemid $=9685$.

Davies, W. and McGoey, L. (2012). "Rationalities of ignorance: On financial crisis and the ambivalence of neo-liberal epistemology", Economy and Society 41(1), 64-83.

Demirgüç-Kunt, A. and Detragiache, E. (1998). "Financial liberation and financial fragility", paper prepared for the Annual World Bank Conference on Development Economics, Washington, D.C., April 20-21, 1998. Retrieved from: http://siteresources.worldbank.org/DEC/Resources/84797-1251813753820/6415739-1251813951236/demirguc.pdf.

Dumenil, G. and Levy, D. (2011). The crisis of neoliberalism. Cambridge: Harvard University Press

Eurostat via Datamarket (2012). Share price indices (rebased) monthly data. Retrieved from http://datamarket.com $/$ data $/ \mathrm{set} / 190 \mathrm{r} / \# \mathrm{ds}=190 \mathrm{r} ! \mathrm{ncy}=3: \mathrm{ncz}=\mathrm{m}$.a.7.t.5. 


\section{STJÓRNSÝSLA}

Eyjolfsdottir, H.M. and Smith, P.B. (1996). "Icelandic business and management culture", International Studies of Management \& Organization 26(3), 61-72.

Fridson, M.S. (1998). It was a very good year: Extraordinary moments in stock market history. New York: John Wiley \& Sons.

Gudmundsdottir, S, Gudlaugsson, T.O., and Adalsteinsson, G.D. (2015). "Icelandic National Culture compared to National Cultures of 25 OECD member states using VSM94”, Icelandic Review of Politics \& Administration 11(1), 19-32. Retrieved from http://www.irpa.is/article/view/a.2014.10.1.2.

Gylfason, T. (2011). "Events in Iceland: Skating on thin ice?", in R.Z. Aliber and G. Zoega (eds.), Preludes to the Icelandic financial crisis, (pp. 290-295). London: Palgrave Macmillan.

Gylfason, T. (2012). "From Collapse to Constitution: The Case of Iceland", CESifo Working Paper Series No. 3770. Available at SSRN: http://ssrn.com/abstract=2034241.

Hoffman, R.C. and Hegarty, W.H. (1993). "Top management influence on innovations: Effects of executive characteristics and social culture", Journal of Management 19(3), 549-574. Retrieved from: http://jom.sagepub.com/cgi/content/abstract/19/3/549.

Hofstede Centre: See http://geert-hofstede.com/countries.html.

Hofstede, G.H., Hofstede J.H., and Minkov, M. (2010). Cultures and organizations: software of the mind: intercultural cooperation and its importance for survival. McGraw-Hill.

Hondroyiannis, G. (2006). "Private saving determinants in European countries: A panel cointegration approach", The Social Science Journal 43, 553-569.

IMF (International Monetary Fund) (2015). World Economic Outlook Database. See http://www.imf.org/ external $/ \mathrm{ns} / \mathrm{cs}$.aspx?id $=28$

Jones, M.L. (2007). "Hofstede - Culturally questionable?”, University of Wollongong. Retrieved from: http:/ / ro.uow.edu.au/cgi/viewcontent.cgi?article=1389\&context=commpapers.

Jonsson, A. (2009). Why Iceland? New York: McGraw Hill.

Jonsson, H.P. (2004). "Menning skipulagsheilda: Tengsl fyrirtækjamenningar og pjóðmenningar. Viðskipta- og hagfræðideild" [The connection of culture within corporations and nations], Reykjavík: Háskóli Íslands, Viðskipta- og hagfræðideild.

Jonung, L., Kiander J., and Vartia P. (2008). "The great financial crisis in Finland and Sweden: The dynamics of boom, bust and recovery, 1985-2000”, European Economy Economic Papers 350 (December), $1-70$.

Johnson, S. and Kwak, J. (2011). 13 bankers: The Wall Street takeover and the next financial meltdown. New York: Random House.

Loftsdottir, K. (2010). "The loss of innocence: The Icelandic financial crisis and colonial past", Anthropology Today 26(6), 9-13. Retrieved from: http://onlinelibrary.wiley.com/doi/10.1111/ j.1467-8322.2010.00769.x/epdf.

Loftsdottir, K. (2015). “'The Danes don't get this': The economic crash and Icelandic postcolonial engagements", National Identities, DOI: 10.1080/14608944.2016.1095491.

Loftsdottir, K. and Mixa, M.W. (2014). "Bankar í ljóma pjóðernishyggju: Efnahagshrunið, hnattvæðing og menning" [Banks Glowing in Nationalism: The Financial Crash, Globalization and Culture], Skirnir (fall), 91-115.

Magala, S. (2015). "Interdisciplinary research of cultural diversity", in Holden, N., Michailova,S., and Tietze, S. (eds.), Routledge Companion to Cross-Cultural Management, (pp. 362-371), London: Routledge.

Magnusson, P., Wilson,R.T., Zdravkovic, S., Zhou, J.X., and Westjohn, S.A. (2008). "Breaking through the cultural clutter: A comparative assessment of multiple cultural and institutional frameworks", International Marketing Review 25(2), 183-201.

Matthiasdottir, S. (2004). Hinn sanni Íslendingur - pjóderni, kyngervi og vald á Íslandi 1900-1930 [The true Icelander - nationality, gender and power in Iceland 1900-1930]. Reykjavík: Háskólaútgáfan.

McSweeney, B. (2002). "Hofstede's model of national cultural differences and their consequences: A triumph of faith - a failure of analysis", Human Relations 55 (1), 89-118. 
Mixa, M.W. (2009). "Once in khaki suits - Socioeconomical Features of the Icelandic Collapse”, in Ingjaldur Hannibalsson (ed.), Rannsóknir i Félagsvísindum X [Research in Social Sciences X], pp. 435-447). Reykjavík: Félagsvísindastofnun Háskóla Íslands.

Newman, K.L. and Nollen, S.D. (1996). "Culture and congruence: The fit between management practices and national culture", Journal of International Business Studies 27(4), 753-779. Retrieved from: http://www.jstor.org/stable/pdfplus/155511.

Olafsson, S. (2003). “The identity of Icelanders: Scandinavian or American?”, Scandinavian Review 91(1). Retrieved from: https://borg.hi.is/IcelandID.pdf.

OMX Iceland: Database

Registers Iceland: Database: See http://www.skra.is/English

Reuter, C.H.J. (2010). "A survey of 'culture and finance", Working paper series. Retrieved from: http:// papers.ssrn.com/sol3/papers.cfm?abstract_id=1317324\&rec=1\&srcabs $=1282068$.

Shiller, R.J. (2001). Irrational exuberance. New York: Broadway Books.

Sigurjonsson, T.O. and Mixa, M.W. (2011). "Learning from the "Worst Behaved". Iceland's Financial Crisis and Nordic Comparison”, Thunderbird International Business Review 53(2), 209-224.

Sigurjonsson, T.O., Schartzkopf, D., and Arnardottir, A.A. (2011). "Viðbrögð tengslanets við gagnrýni á fjármálastöðugleika Íslands”, Stjórnmál \& stjórnsýsla 7(1), 161-184. Retrieved from: http:/ /skemman. is/stream/get/1946/9660/24597/4/a.2011.7.1.9.pdf.

Smith, P.B., Andersen, J.A., Ekelund, B., Graversen, G., and Ropo, A. (2003). "In search of Nordic management styles", Scandinavian Journal of Management 19, 491-507. Retrieved from http://www. sciencedirect.com/science/article/pii/S0956522103000368.

Soares, A.M., Farhangmehr, M., and Shoham, A. (2007). "Hofstede's dimensions of culture in international marketing studies”, Journal of Business Research, 60, 277-284. Retrieved from: http://www. sciencedirect.com/science/article/pii/S0148296306001974.

Steger, M.B. and Roy, R. (2007). Neoliberalism: a very short introduction. New York: Oxford University Press.

Thorvaldsson, A. (2009). Ævintýraeyjan - Uppgangur og endalok fjármálaveldis [Icelandic version: Frozen Assets: How I lived Iceland's boom and bust]. Reykjavík: Bókaforlagið.

Trompenaars, F. and Hampden-Turner, C. (1998). Riding the waves of culture: Riding diversity in global business (2nd edition). New York: McGraw-Hill.

Vaiman, V. and Holden, N. (2015). "Cross-cultural management: arguing the case for non-cultural explanations”, in Holden, N., Michailova,S., and Tietze, S. (eds.), Routledge Companion to Cross-Cultural Management, (pp. 56-68), London: Routledge.

Vaiman, V., Sigurjonsson, T.O., and Davidsson, P.A. (2010). "Weak business culture as an antecedent of economic crisis: the case of Iceland", Journal of Business Ethics 98, 259-272.

World Bank (citing: International Monetary Fund, International Financial Statistics and data files, and World Bank and OECD GDP estimates) via Datamarket (2013). Domestic credit provided by financial sector (\% of GDP). Retrieved from http://datamarket.com/data/set/149b/\#!display=line\&ds=149 $\mathrm{b} ! \mathrm{gah}=2 \mathrm{i} .2 \mathrm{z} \cdot 1 \mathrm{z} \cdot 1 \mathrm{w} \cdot 4 \mathrm{e}$.

World Bank database: Market capitalization of listed companies (\% of GDP). Retrieved from:_http://data. worldbank.org/indicator/CM.MKT.LCAP.GD.ZS.

Zoega, G. (2010). "Hver borgar brúsann?" [Who pays the bill?]. Vishending 8(36), 1-4. 
